\title{
ANTIFUNGAL ACTIVITY OF Heteranthera reniformis EXTRACTS AGAINST Bipolaris oryzae ${ }^{1}$
}

\author{
LAÍS TESSARI PERBONI ${ }^{2 *}$, DIRCEU AGOSTINETTO ${ }^{2}$, CANDIDA RENATA JACOBSEN DE FARIAS ${ }^{3}$, \\ FÁBIO CLASEN CHAVES ${ }^{4}$, JÉSSICA RODRIGUES GARCIA ${ }^{2}$
}

\begin{abstract}
Plants synthesize specialized metabolites to defend themselves against pathogens. These active compounds, when isolated and identified, can be used as template for fungicide development. Based on field observations, Heteranthera reniformis (kidney leaf mudplantain) could potentially synthesize compounds with antifungal activity. The goal of this study was to evaluate the fungicidal activity of $H$. reniformis leaf extracts on Bipolaris oryzae development. The activities of hexane, ethyl acetate, and methanol extracts of $H$. reniformis leaves were tested on mycelial growth, sporulation, and colony morphology. Due to the highest inhibition of $B$. oryzae sporulation, methanol extract was chosen for concentration tests. The effect of methanol extract on B. oryzae spore length and germination was also evaluated. Methanolic extract was the most active in inhibiting B. oryzae sporulation. The morphology of the colonies is altered when the fungus grows in medium containing $H$. reniformis leaf extracts. Higher concentration of methanol extract stimulates mycelial growth and suppresses $B$. oryzae sporulation. There are reductions in length and number of germinated $B$. oryzae spores caused by methanol extract of $H$. reniformis leaves. Methanolic extract has compounds with antifungal activity and should be subjected to bioassay-guided isolation for purification and identification of these active compounds.
\end{abstract}

Keywords: Kidney leaf mudplantain. Extracts. Rice brown leaf spot.

\section{ATIVIDADE ANTIFÚNGICA DE EXTRATOS DE Heteranthera reniformis SOBRE Bipolaris oryzae}

RESUMO - As plantas sintetizam metabólitos especializados para defenderem-se contra patógenos. Estes compostos ativos, quando isolados e identificados, podem ser utilizados como modelos para o desenvolvimento de fungicidas. Baseado em observações a campo, as plantas de Heteranthera reniformis (aguapé-mirim) são promissoras na síntese de compostos com atividade antifúngica. O objetivo deste estudo foi avaliar a atividade antifúngica de extratos de $H$. reniformis sobre o desenvolvimento de Bipolaris oryzae. A atividade dos extratos hexano, acetato de etila e metanol de folhas de H. reniformis foi avaliada no crescimento micelial e esporulação de $B$. oryzae. Devido a maior inibição da esporulação de $B$. oryzae, o extrato metanólico foi escolhido para o experimento de concentrações. O efeito do extrato metanólico sobre a morfologia das colônias, comprimento e germinação dos esporos de $B$. oryzae também foi avaliado. Os resultados demonstraram que o extrato metanólico foi o mais ativo na inibição da esporulação de $B$. oryzae. A morfologia das colônias é alterada quando o fungo cresce em meio contendo extratos foliares de $H$. reniformis. As maiores concentrações do extrato metanol estimulam o crescimento micelial e suprimem a esporulação de $B$. oryzae. Há reduções no comprimento e germinação de esporos de B. oryzae pelo extrato metanólico de folhas de $H$. reniformis. O extrato metanólico tem compostos com atividade antifúngica e deve ser submetido ao isolamento guiado por bioensaio para a purificação e identificação destes compostos.

Palavras-chaves: Aguapé-mirim. Extratos. Mancha parda do arroz.

\footnotetext{
"Corresponding author

${ }^{1}$ Received for publication in 06/07/2020; accepted in 02/04/2021.

Paper extracted from the doctoral thesis of the first author.

${ }^{2}$ Department of Crop Protection, Herbology Center, Universidade Federal de Pelotas, Pelotas, RS, Brazil; laliperboni@hotmail.com ORCID: 0000-0002-4484-5799, agostinetto.d@gmail.com - ORCID: 0000-0001-6069-0355, jejesvp@hotmail.com - ORCID: 0000-00032146-8625.

${ }^{3}$ Department of Crop Protection, Seed Pathology Laboratory, Universidade Federal de Pelotas, Pelotas, RS, Brazil; jacobsencandida@gmail.com - ORCID: 0000-0002-3761-7165.

${ }^{4}$ Department of Food Science and Technology, Chromatography and Mass Spectrometry Laboratory, Universidade Federal de Pelotas, Pelotas, RS, Brazil; chavesfc@gmail.com - ORCID: 0000-0002-5773-0800.
} 


\section{INTRODUCTION}

Irrigated rice cultivation in the 2019/20 harvest in Brazil occupied a total area of 1,286 thousand hectares (ha), where 9,744.5 thousand tons of grains were produced, resulting in an average yield of $7,530 \mathrm{~kg} \mathrm{ha}{ }^{-1}$ (CONAB, 2020). The productive potential of rice cultivars can be higher than 10 tons $\mathrm{ha}^{-1}$ when cultivated under appropriate phytosanitary management.

Brown spot caused by the etiological agent Bipolaris oryzae (Breda de Haan) Shoem stands out as one of the main fungal diseases in rice causing relevant economic impact (ROSSMAN; MANAMGODA; HYDE, 2013). This disease affects seed germination, emergence of rice seedlings, reduces photosynthetic rate due to leaf lesions, causes sterility of spikelets, and leads to stained grains, causing losses in yield and in grain quality (BEDENDO; PRABHU, 2016).

Chemical control, using fungicides, corresponds to one of $B$. oryzae management strategies, but there is need for new compounds with different modes of action to fight the increase of plant pathogens' resistance to currently available fungicides. Thus, the importance of discovering new active molecules against plant pathogens is emphasized (KUCK; LEADBEATER; GISI, 2012).

Research towards the development of new pesticides has been based on natural products from microorganisms or plants (SPARKS; HAHN; GARIZI, 2017). The discovery of new pesticide based on natural products begins with the selection of the organism with potential to produce bioactive compounds, followed by the extraction of these compounds with solvents of different polarities and testing of the extracts in bioassays (DAS, 2016). Active extracts are then fractionated and further purified and isolated in order to determine the chemical structure of the compounds present in them using spectrometric and spectroscopic techniques for identification of organic compounds (IMATOMI et al., 2013). These compounds can serve as models for the development of new synthetic fungicides, in the same way as the fungicides of the strobilurins group, which are examples of synthetic fungicides based on natural products produced by fungi (CANTRELL; DAYAN; DUKE, 2012). Fungicides based on natural products are considered safer, because they are less toxic to humans and animals, biodegrade more easily, and persist less in the environment (MARTÍNEZ-ROMERO et al., 2008).

Kidney leaf mudplantain (Heteranthera reniformis Ruiz \& Pav.) is an aquatic and invasive plant that occurs in irrigated rice areas. H. reniformis young leaves are wrapped by a ligule filled with a mucilaginous substance (FARIA; AMARAL, 2005). This substance, of unknown composition, and/or other compounds present it its leaves apparently protect them against pathogens since no fungal disease has been observed in this plant and, therefore, it can constitute a source of compounds with fungicidal potential.

Within this context, this study had as hypotheses that $H$. reniformis extracts have fungicidal activity and this activity is dependent on the concentration of the extract. The objective was to evaluate the activity of $H$. reniformis leaf extracts on the development of different isolates of B. oryzae.

\section{MATERIAL AND METHODS}

The experiments were performed in greenhouse and laboratories of the Herbology and Seed Pathology Center of Eliseu Maciel Agronomy School of the Federal University of Pelotas (FAEM/ UFPel). In order to collect plant material for the extraction, $H$. reniformis plants were grown in $45 \mathrm{~L}$ boxes containing sandy soil from rice field classified as Planosol. Leaves free of injuries were collected, washed, and dried for seven days in a forced air circulation oven at $40{ }^{\circ} \mathrm{C}$. The dry material was ground with the aid of a ball mill, adding liquid nitrogen during the grinding process, and subsequently stored in a freezer at $-20{ }^{\circ} \mathrm{C}$ until extraction.

B. oryzae isolates were obtained from infected rice seeds and preserved in PDA (potato dextrose agar) medium at $-5{ }^{\circ} \mathrm{C}$ in the Seed Pathology laboratory library of FAEM/UFPel. In experiments 1,3 , and 4 an isolate of intermediate aggressiveness was used (LP6, isolates from Pelotas with KX344513 GenBank code). In experiment 2, three isolates of $B$. oryzae were used: one of low aggressiveness (LPS07, isolated from Camaquã with JF521648 GenBank code), one isolate of intermediate aggressiveness (LP06, isolates from Pelotas with KX344513 GenBank code), and one of high aggressiveness (LPS08, isolates from Santo Antônio da Patrulha with XM007701 GenBank code). These were identified and categorized according to their level of aggressiveness by Moreira -Nunez (2017). Fungal isolates were replicated into Petri dishes containing fresh PDA and kept at $24{ }^{\circ} \mathrm{C}$ under a 12-hour light period for 10 days.

The extraction of the dry and ground plant material of $H$. reniformis was performed with hexane, ethyl acetate, and methanol solvents at plant mass to solvent volume ratio of 1:10 (m/v). Forty $\mathrm{mL}$ 
of each solvent were added to Erlenmeyer flasks containing four grams of plant material, which were placed in an ultrasound bath for 30 minutes. The extract was centrifuged at 4,000 $x \mathrm{~g}$, for 10 minutes. The supernatant was collected and transferred to a tared round bottom flask and subsequently the solvent was evaporated under reduced pressure until complete solvent removal. The remaining residue after solvent evaporation was resuspended with a dimethyl sulfoxide (DMSO) and water mixture $\left(0.5 \%\right.$ in autoclaved water) to make up $0.8 \mathrm{mg} \mathrm{mL}^{-1}$, $2 \mathrm{mg} \mathrm{mL} \mathrm{m}^{-1}$, or $4 \mathrm{mg} \mathrm{mL}^{-1}$ solutions, depending on the experiment. The preparation of the solutions was performed in a laminar flow hood, using sterilized glassware, to avoid potential contaminations.

Experiment 1 - Evaluation of different $H$. reniformis leaves extracts in the suppression of $B$. oryzae

In this experiment, the treatments consisted of hexane, ethyl acetate, and methanol extracts, at the concentration of $0.4 \mathrm{mg} \mathrm{mL}^{-1}$, and the controls: PDA, $\mathrm{PDA}+\mathrm{DMSO}$, and Vitavax fungicide (Carboxin + Thiram) at the concentration of $140 \mu \mathrm{L} \mathrm{mL}{ }^{-1}$ of medium, totaling six treatments. The PDA+DMSO control was used to verify any DMSO interference on fungal development. The experimental design was completely randomized with six replicates. The experimental units consisted of Petri dishes containing $10 \mathrm{~mL}$ of growing media. To obtain the desired concentration, the solution containing the extract was mixed with fused PDA, previously autoclaved, and the blend poured into Petri dishes.

A $5 \mathrm{~mm}$ (diameter) disk of B. oryzae mycelial mat (isolate with intermediate aggressiveness) was placed in the center of each Petri dish containing solidified media. The dishes were sealed with Parafilm and kept in a growth chamber at $25^{\circ} \mathrm{C}$ with 12 hours/light/day photoperiod.

Mycelial growth measurements were performed daily, with the aid of a millimetric ruler, until one of the colonies reached the edge of the dish, taking into account the average of two orthogonal diameters of the developing colonies and calculation of mycelial growth index (MGI). MGI was calculated from the formula: $\mathrm{MGI}=\mathrm{C}_{1}+\mathrm{C}_{2}+\ldots \mathrm{C}_{7} /$ $\mathrm{N}_{1}+\mathrm{N}_{2}+\ldots \mathrm{N}_{7}$, where: $\mathrm{C}_{1}, \mathrm{C}_{2}, \mathrm{C}_{7}$ means the growth of the colonies in the first, second and last evaluation and $\mathrm{N}_{1}, \mathrm{~N}_{2}$ and $\mathrm{N}_{7}$, the number of days.
For the determination of the number of spores $\mathrm{mL}^{-1}$, performed when the fungal colonies reached the dishes' edges, four disks were removed from each Petri dish and placed in test tubes containing $10 \mathrm{~mL}$ of autoclaved distilled water and a drop of Tween 80, to obtain a homogeneous spore suspension. The test tubes containing the growth disks were vortexed and aliquots were pipetted on two quadrants of the Neubauer chamber for two spore counts per replicate. B. oryzae isolate colonies were evaluated according to form, elevation, margin, and color based on the microbiological scale of Pelczar (1957), and the soil color charts according to Munsell (1975).

Data from this experiment were submitted to analysis of variance (ANOVA $\mathrm{p} \leq 0.05$ ) and, in case of statistical significance, treatment means comparisons were evaluated by Duncan's test $(\mathrm{p} \leq 0.05)$.

Experiment 2 - Concentrations effects of $H$. reniformis methanol extract on the growth of $B$. oryzae isolates

After determining the most active extract, concentration experiments were performed, where concentrations of $0,0.0001,0.001,0.01,0.01,0.1,1$, and $2 \mathrm{mg} \mathrm{mL}^{-1}$ of methanol extract of $H$. reniformis leaves were tested on the growth of $B$. oryzae isolates of intermediate, high and low aggressiveness (MOREIRA-NUNEZ, 2017). Extract dilutions were obtained from stock extract solutions of 2 or $4 \mathrm{mg}$ $\mathrm{mL}^{-1}$ for the experiments with up to 1 and $2 \mathrm{mg} \mathrm{mL}^{-1}$, respectively. PDA and PDA+DMSO control treatments were also included in this experiment, in order to perform a contrast analysis. The concentration of $0 \mathrm{mg} \mathrm{mL} \mathrm{m}^{-1}$ consisted of PDA, DMSO mixture and the remaining residue after methanol evaporation, in order to verify possible negative effect of solvent contaminants on the fungus.

The experimental design, number of replicates, experimental units, colony growth measurements and score of spore number $\mathrm{mL}^{-1}$ were the same as those described in experiment 1 . For the statistical analysis, after verifying the significance in the ANOVA, treatments were compared to controls using contrast analysis (Table 1), and the concentrations were compared by confidence intervals $(95 \%)$. 
Table 1. Treatments and contrasts used in the growth experiments of Bipolaris oryzae isolates (high aggressiveness, intermediate aggressiveness, and low aggressiveness) with different concentrations of methanol extract of Heteranthera reniformis leaves.

\begin{tabular}{|c|c|c|c|c|c|c|c|}
\hline Treatment & $\mathrm{C} 1^{5} \mathrm{C} 2$ & $\mathrm{C} 3$ & $\mathrm{C} 4$ & $\mathrm{C} 5$ & C6 & $\mathrm{C} 7$ & $\mathrm{C} 8$ \\
\hline T1-PDA ${ }^{1}$ & $+^{4}$ & + & + & + & + & + & + \\
\hline $\mathrm{T} 2-\mathrm{PDA}+\mathrm{DMSO}^{2}$ & + & + & + & + & + & + & + \\
\hline T3- PDA+DMSO+Solvent Residue+Extract $0 \mathrm{mg} \mathrm{mL}^{-1}$ & - & + & + & + & + & + & + \\
\hline T4- PDA+DMSO+Solvent Residue+ Extract $0.0001 \mathrm{mg} \mathrm{mL}^{-1}$ & & - & & & & & \\
\hline T5- PDA+DMSO+Solvent Residue+Extract $0.001 \mathrm{mg} \mathrm{mL}^{-1}$ & & & - & & & & \\
\hline T6- PDA+DMSO+Solvent Residue+Extract $0.01 \mathrm{mg} \mathrm{mL}^{-1}$ & & & & - & & & \\
\hline T7- PDA+DMSO+Solvent Residue+Extract $0.1 \mathrm{mg} \mathrm{mL}^{-1}$ & & & & & - & & \\
\hline T8- PDA+DMSO+Solvent Residue+Extract $1 \mathrm{mg} \mathrm{mL}^{-1}$ & & & & & & - & \\
\hline T9- PDA+DMSO+Solvent Residue+Extract $2 \mathrm{mg} \mathrm{mL}^{-13}$ & & & & & & & - \\
\hline
\end{tabular}

${ }^{1}$ PDA: Potato, dextrose, and agar culture medium; ${ }^{2}$ DMSO: Dimethyl sulfoxide; ${ }^{3}$ Treatment 9 with concentration of 2 mg $\mathrm{mL}^{-1}$ was used only for the intermediate aggressiveness isolate. ${ }^{4}+$ or - indicate which treatments were used for the contrast formation. ${ }^{5} \mathrm{C} 1, \mathrm{C} 2, \mathrm{C} 3, \mathrm{C} 4, \mathrm{C} 5, \mathrm{C} 6, \mathrm{C} 7$ and $\mathrm{C} 8$ : Contrasts 1 to 8 .

Experiment 3 - Effect of methanol extract of $\boldsymbol{H}$. reniformis on the size of $B$. oryzae spores

Microculture slides were prepared to evaluate spore size in media containing methanol extract. The experimental design used was completely randomized, with 11 replicates. The treatments consisted of methanol extract $\left(0.4 \mathrm{mg} \mathrm{mL}^{-1}\right)$ and the PDA and PDA+DMSO controls, prepared as described in experiment 1 . The medium containing the extract and the controls were poured into Petri dishes, and after solidification these were cut in cuboid shape $(3 \times 6 \times 3 \mathrm{~mm})$. The pieces were placed on glass slides, and the eight vertices inoculated with $B$. oryzae isolate of intermediate aggressiveness and the inoculated cuboid covered with a microslide. The slide+cuboid+microslide set was placed inside a sterilized glass Petri dish containing a blotting paper moistened with autoclaved distilled water.

After fungal growth on both surfaces (the bottom, touching the slide, and the top in contact with the microslide) the cuboid was removed and Amann blue dye was added to one of the surfaces while lactophenol was added to the other. Then the diameter and length of ten spores per replicate were measured using the ruler of the stereoscope microscope lens (multiplied by a correction factor according to the size of the lens used).

Data from this experiment were submitted to analysis of variance (ANOVA $\mathrm{p} \leq 0.05$ ) and, in case of statistical significance, treatment means were compared by Duncan's test $(\mathrm{p} \leq 0.05)$.

Experiment 4 - Effect of methanol extract of $\boldsymbol{H}$. reniformis leaves on the germination of $B$. oryzae spores

In this experiment, the treatments consisted of distilled water; distilled water+DMSO; distilled water+DMSO+methanol solvent residue after evaporation; and, distilled water+DMSO+methanol solvent residue + methanol extract of $H$. reniformis leaves $\left(0.4 \mathrm{mg} \mathrm{mL}^{-1}\right.$ and $\left.0.8 \mathrm{mg} \mathrm{mL}^{-1}\right)$. The control containing the solvent residue was used to verify possible negative effects of the impurities potentially present from the solvent remnants on the development of the pathogen.

$B$. oryzae fungus of intermediate aggressiveness was multiplied in four Petri dishes with PDA (growing conditions described in experiment 1) for ten days. Subsequently, the dish that had the best sporulation (as visualized under a magnifying glass) was used for the inoculum preparation. After mycelial growth and sporulation, $10 \mathrm{~mL}$ of sterilized distilled water were added to the Petri dish, and with the aid of a sterilized brush, the spore mass and mycelia were homogenized. The suspension was filtered through cheesecloth in a funnel and collected in a test tube. The inoculum concentration was then adjusted to $10^{4}$ spores $\mathrm{mL}^{-1}$ using a Neubauer chamber to count the spores, according to methodology described by Silva et al. (2018). Controls and extract solutions were prepared as described in experiment 1.

Each well of a 96-well plate, representing an experimental unit, received $100 \mu \mathrm{L}$ of the $B$. oryzae (isolate of intermediate aggressiveness) spore solution, $100 \mu \mathrm{L}$ of $H$. reniformis methanol extract and an appropriate volume of water to obtain a final extract concentration of 0.4 and $0.8 \mathrm{mg} \mathrm{mL}^{-1}$. The experimental design used was completely randomized with 12 replicates, and ten spores were evaluated per replicate. Spores were randomly selected 24 hours after the treatment application to determine the number of non-germinated spores. Data were presented in percentage of nongerminated spores $(\%)$.

After verifying the significance in ANOVA, treatment means were compared to the controls using contrast analysis (Table 2). 
Table 2. Treatments and contrasts used in the germination experiments of Bipolaris oryzae isolate of intermediate aggressiveness in media containing methanol extract of Heteranthera reniformis leaves.

\begin{tabular}{lccc}
\hline \multicolumn{1}{c}{ Treatment } & $\mathrm{Cl}^{2}$ & $\mathrm{C} 2$ & $\mathrm{C} 3$ \\
\hline T1- Distilled water & + & & + \\
T2- Distilled water+DMSO & & & + \\
T3- Distilled water+DMSO+ Solvent Residue & - & + & + \\
T4- Distilled water+DMSO+ Solvent Residue + Extract & & \\
\hline
\end{tabular}

${ }^{1}$ DMSO: Dimethyl sulfoxide; ${ }^{2}$ Concentration of methanol extract of 0.4 and $0.8 \mathrm{mg} \mathrm{mL}{ }^{-1} ;{ }^{3} \mathrm{C} 1, \mathrm{C} 2$ and $\mathrm{C} 3$ : Contrasts 1,2 and $3 ;{ }^{4}+$ or - indicate which treatments were used for the contrast formation.

\section{RESULTS AND DISCUSSION}

\section{Experiment 1}

In experiment 1 , the mycelial growth index (MGI) was higher when the fungus grew in media containing $H$. reniformis extracts than in the media without the extract and was totally inhibited by the fungicide (Table 3). Among the three H. reniformis extracts, the highest mycelial growth was observed in the ethyl acetate treatment, which differed from the others. The controls had MGIs lower than those of the treatments containing the extracts, and the lowest growth was verified in the control treatment with the DMSO adjuvant.

Table 3. Mycelial growth index (MGI) and spores $\mathrm{mL}^{-1}$ of Bipolaris oryzae in different Heteranthera reniformis leaf extracts.

\begin{tabular}{lccccc}
\hline \multicolumn{1}{c}{ Treatment } & MGI & & ${\text { spores } \mathrm{mL}^{-1}}$ \\
\hline PDA Control $^{1}$ & 8.13 & & $\mathrm{c}^{3}$ & 6354 & \\
DMSO Control $^{2}$ & 4.92 & $\mathrm{~d}$ & 6771 & $\mathrm{a}$ \\
Hexane extract $_{\text {Ethyl acetate extract }}$ & 11.38 & $\mathrm{~b}$ & 1979 & $\mathrm{a}$ \\
Methanol extract & 11.88 & $\mathrm{a}$ & 2813 & $\mathrm{bc}$ \\
Fungicide & 11.41 & & $\mathrm{~b}$ & 625 & $\mathrm{c}$ \\
\hline \multicolumn{1}{c}{$\mathrm{CV}(\%)$} & 0 & $\mathrm{e}$ & 0 & $\mathrm{~d}$ \\
\hline
\end{tabular}

${ }^{1}$ PDA: potato dextrose and agar; ${ }^{2}$ DMSO: Dimethyl sulfoxide; ${ }^{3}$ Means followed by the same letter within a column do not differ by Duncan's test $(\mathrm{p} \leq 0.05)$.

Excluding the fungicide treatment, sporulation response was contrary to mycelial growth response, where the treatment with lower MGI (DMSO control) showed higher sporulation and did not differ from the PDA control treatment (Table 3 ). The lowest sporulation was verified when the methanol extract was used, followed by hexane extract and ethyl acetate.

The mycelial growth stimulus and sporulation inhibition in treatments containing $H$. reniformis leaf extracts were accompanied by a change in colony color (Table 4). In general, there were no changes in the form, elevation, and margin of $B$. oryzae colony in all treatments, except for PDA treatment, in which mycelia showed a filamentous margin. Regarding color, treatments containing the plant extracts had lighter colonies compared to the controls, indicating the presence of sectors, with varying color from bluish gray to greenish gray and presence of white cottony mycelium above the colonies. The formation of sectors in the colony can be a variability source that reveals somatic mutations (CAMARGO, 1995), and can be a possible cause of new genetic variants of pathogens.

Table 4. Form, elevation, margin, and color of Bipolaris oryzae colony in growth media containing different Heteranthera reniformis leaf extracts.

\begin{tabular}{lcccc}
\hline \multicolumn{1}{c}{ Treatment } & Form & Elevation & Margin & Color $^{1}$ \\
\hline $\mathrm{PDA}^{2}$ & irregular & elevated & filamentous & dark bluish gray or dark greenish gray (gley 2-4.1) \\
$\mathrm{DMSO}^{3}$ & irregular & elevated & wavy & dark greenish gray (gley 2-3.1) \\
Methanol & irregular & elevated & wavy & bluish gray (gley 2-6.1) \\
Ethyl acetate & irregular & elevated & wavy & greenish gray (gley 2-5.1) \\
Hexane & irregular & elevated & wavy & greenish gray (gley 2-6.1) \\
\hline
\end{tabular}

${ }^{1}$ Color based on Munsell soil color charts (1975). ${ }^{2}$ PDA: Potato, dextrose and agar culture medium; ${ }^{3}$ DMSO: Dimethyl sulfoxide. 
Contrary to these findings, when evaluating the effect of plant extracts on the development of pathogens, it is common to observe mycelial growth inhibition (KHAN; NASREEN, 2010; MINZ; SAMUEL; TRIPATHI, 2012). However, $H$. reniformis extracts caused modifications of the colonies and compromised the sporulation and aggressiveness of $B$. oryzae. Likewise, in a study by Kumar et al. (2016), the maximum sporulation was observed in isolates that showed suppressed colony growth and darkened color, and minimal sporulation was verified in isolates with colonies containing cottony mycelium, of gray or white color.

Similar to what was observed in this study, Bhutia, Ramen and Saha (2016) also found methanol extract of Pongamia pinnata, Allium sativum, and Annona squamosa as the most active in the suppression of mycelial growth and sporulation of Colletotrichum musae when compared to other extraction solvents. Other studies also suggest that methanol provides greater extractability of antimicrobial compounds from plants when compared to other solvents (TATA et al., 2018; GURJAR et al., 2012). However, plant species are remarkably diverse in the constitution of antimicrobial compounds, so depending on the chemical structure of the active compound other solvents might provide better extraction yields (TATA et al., 2018).

The methanol extract treatment was chosen as the most active extract (leads to lower sporulation values) for the follow-up concentration test on the development of three $B$. oryzae isolates with different levels of aggressiveness (Experiment 2).

\section{Experiment 2}

Mycelial growth data of the low aggressiveness isolate showed similar behavior to those of the intermediate and more aggressive isolates (data not shown). However, the sporulation of this isolate was not determined, due to intense formation of sectors in the colonies in all treatments and controls, indicating presence of mutations.

MGIs and sporulation data of $B$. oryzae isolates of intermediate and high aggressiveness showed statistical significance and were submitted to contrast analysis (Table 5). For the intermediate isolate, in the contrast of PDA+DMSO vs $\mathrm{PDA}+\mathrm{DMSO}+$ solvent residue after evaporation, a negative effect of solvent residue was verified only on MGI. However, this result was not considered negative interference since the extract stimulated mycelial growth. It is usually a good practice to verify toxicity and interference of residue and solvent contaminants on bioassays (NCUBE; AFOLAYAN; OKOH, 2008).

Except for concentrations of 0.0001 (contrast 3) and $0.001 \mathrm{mg} \mathrm{mL}^{-1}$ (contrast 4), all other extract concentrations stimulated mycelial growth of the isolate of intermediate aggressiveness compared to the controls (Table 5). Reduced sporulation was verified when control PDA was used alone (contrast 1). However, the other controls, considered more comprehensive, because they contain DMSO and solvent residue in addition to PDA, had significant sporulation.

Table 5. Mycelial growth index (MGI) and sporulation of Bipolaris oryzae isolates of intermediate and high aggressiveness, and significance of the tested contrasts.

\begin{tabular}{|c|c|c|}
\hline \multicolumn{3}{|c|}{ Isolate of intermediate aggressiveness } \\
\hline Contrasts & MGI & spores $\mathrm{mL}^{-1}$ \\
\hline $\mathrm{C1}^{2}-(\mathrm{T} 1) \mathrm{x}(\mathrm{T} 2)$ & $(6.23)^{\mathrm{ns} 1} \mathrm{x}(6.01)$ & $(650)^{*} \times(1,417)$ \\
\hline $\mathrm{C} 2-(\mathrm{T} 2) \mathrm{x}(\mathrm{T} 3)$ & $(6.01)^{*} \times(4.99)$ & $(1,417)^{\mathrm{ns}} \times(1,292)$ \\
\hline $\mathrm{C} 3-(\mathrm{T} 1+\mathrm{T} 2+\mathrm{T} 3) \mathrm{x}(\mathrm{T} 4)$ & $(5.75)^{\mathrm{ns}} \times(6.15)$ & $(1,120)^{\mathrm{ns}} \times(541)$ \\
\hline $\mathrm{C} 4-(\mathrm{T} 1+\mathrm{T} 2+\mathrm{T} 3) \mathrm{x}(\mathrm{T} 5)$ & $(5.75)^{\mathrm{ns}} \times(6.06)$ & $(1,120)^{\mathrm{ns}} \times(550)$ \\
\hline $\mathrm{C} 5-(\mathrm{T} 1+\mathrm{T} 2+\mathrm{T} 3) \times(\mathrm{T} 6)$ & $(5.75)^{*} \times(6.88)$ & $(1,120)^{*} \times(458)$ \\
\hline C6- (T1+T2+T3)x(T7) & $(5.75)^{*} \times(7.34)$ & $(1,120)^{*} \times(250)$ \\
\hline $\mathrm{C} 7-(\mathrm{T} 1+\mathrm{T} 2+\mathrm{T} 3) \mathrm{x}(\mathrm{T} 8)$ & $(5.75)^{*} \times(7.91)$ & $(1,120)^{*} \times(50)$ \\
\hline $\mathrm{C} 8-(\mathrm{T} 1+\mathrm{T} 2+\mathrm{T} 3) \mathrm{x}(\mathrm{T} 9)$ & $(5.75)^{*} \times(7.64)$ & $(1,120)^{*} \times(125)$ \\
\hline $\mathrm{CV}(\%)$ & 10.1 & 101.6 \\
\hline \multicolumn{3}{|c|}{ Isolate of high aggressiveness } \\
\hline $\mathrm{C} 1-(\mathrm{T} 1) \times(\mathrm{T} 2)$ & $(5.25)^{\mathrm{ns}} \times(5.11)$ & $(3,799)^{\mathrm{ns}} \times(2,000)$ \\
\hline $\mathrm{C} 2-(\mathrm{T} 2) \times(\mathrm{T} 3)$ & $(5.11)^{\mathrm{ns}} \times(5.03)$ & $(2,000)^{\mathrm{ns}} \times(2,688)$ \\
\hline $\mathrm{C} 3-(\mathrm{T} 1+\mathrm{T} 2+\mathrm{T} 3) \times(\mathrm{T} 4)$ & $(5.13)^{\mathrm{ns}} \times(5.48)$ & $(2,829)^{\mathrm{ns}} \times(1,300)$ \\
\hline $\mathrm{C} 4-(\mathrm{T} 1+\mathrm{T} 2+\mathrm{T} 3) \mathrm{x}(\mathrm{T} 5)$ & $(5.13)^{\mathrm{ns}} \times(5.30)$ & $(2,829)^{\mathrm{ns}} \times(3,375)$ \\
\hline $\mathrm{C} 5-(\mathrm{T} 1+\mathrm{T} 2+\mathrm{T} 3) \times(\mathrm{T} 6)$ & $(5.13)^{\mathrm{ns}} \times(5.55)$ & $(2,829)^{\mathrm{ns}} \times(1350)$ \\
\hline C6- (T1+T2+T3)x(T7) & $(5.13)^{*} \times(7.72)$ & $(2,829)^{*} \times(650)$ \\
\hline $\mathrm{C} 7-(\mathrm{T} 1+\mathrm{T} 2+\mathrm{T} 3) \times(\mathrm{T} 8)$ & $(5.13)^{*} \times(9.85)$ & $(2,829)^{*} \times(150)$ \\
\hline $\mathrm{CV}(\%)$ & 16.4 & 106.6 \\
\hline
\end{tabular}

${ }^{1 *}$ or $^{\mathrm{n}}$ significant and non-significant contrasts $(\mathrm{p} \leq 0.05) .{ }^{2} \mathrm{C} 1, \mathrm{C} 2, \mathrm{C} 3, \mathrm{C} 4, \mathrm{C} 5, \mathrm{C} 6, \mathrm{C} 7, \mathrm{C} 8$ : Contrasts 1 to 8. 
Sporulation results were contrary to those of mycelial growth (Table 5). Concentrations of $H$. reniformis leaves extracts from $0.01 \mathrm{mg} \mathrm{mL}^{-1}$ (contrast 5) showed reductions compared to the controls. Extract concentrations of 1 and $2 \mathrm{mg} \mathrm{mL}^{-1}$ (contrasts 7 and 8 ) reduced sporulation by 22.4 and 8.9 times, respectively, when compared to the control treatments. The sporulation reduction caused by $H$. reniformis leaf extracts constitutes a relevant result for the management of diseases, since the sporulation stimulus would increase the incidence and aggressiveness of the disease and the quantity of spores dispersed to new areas and cultures (TATA et al., 2018). Spores are the main dispersing unit of plant pathogenic fungi, enabling them to reach hosts at long distances.

For the high aggressiveness isolate, mycelial growth and sporulation reduction was also verified according to the increase of the concentration of methanol extract of $H$. reniformis (Table 5). The addition of DMSO adjuvant and the solvent residue did not affect MGIs or spores $\mathrm{mL}^{-1}$. For both variables, there was no difference between the controls and the concentrations of 0.0001 (contrast 3) and $0.01 \mathrm{mg} \mathrm{mL} \mathrm{mL}^{-1}$ (contrast 5). For the concentrations of 0.1 (contrast 6) and $1 \mathrm{mg} \mathrm{mL} \mathrm{mL}^{-1}$ (contrast 7), increased MGIs and suppression of $B$. oryzae sporulation were observed. The high aggressiveness isolate proved to be less sensitive to methanol extract, considering that the sporulation inhibition occurred at the concentration of $0.1 \mathrm{mg} \mathrm{mL}^{-1}$.

Regarding concentrations, the control had the lowest MGI of $B$. oryzae intermediate aggressiveness isolate and did not differ from the concentrations of 0.0001 and $0.001 \mathrm{mg} \mathrm{mL}^{-1}$ of $H$. reniformis methanol extract (Figure 1. 1A). The concentration of $0.01 \mathrm{mg} \mathrm{mL}^{-1}$ led to higher MGI compared to the control, but did not differ from the concentrations of $0.0001,0.001$ and $0.1 \mathrm{mg} \mathrm{mL}^{-1}$. The highest MGIs were observed at the concentration of $1 \mathrm{mg} \mathrm{mL}^{-1}$ and this differed from all concentrations, including control.

Necrotrophic fungi, such as $B$. oryzae, have survival strategies and accelerate their growth to protect themselves from the reactive oxygen produced by the hosts during hypersensitivity responses (MAYER; STAPLES; GIL-AD, 2001). This mycelial growth increase may also be a strategy to avoid $H$. reniformis antifungal compounds present in the media.

The highest sporulation of the $B$. oryzae intermediate aggressiveness isolate was observed in the control treatment, and this differed from all concentrations (Figure 1. 1B). The concentrations

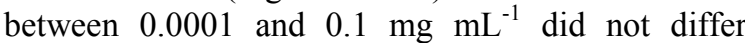
among themselves but promoted sporulation suppression. The highest suppression was observed at the highest extract concentration; however, this did not differ from $0.1 \mathrm{mg} \mathrm{mL}^{-1}$.
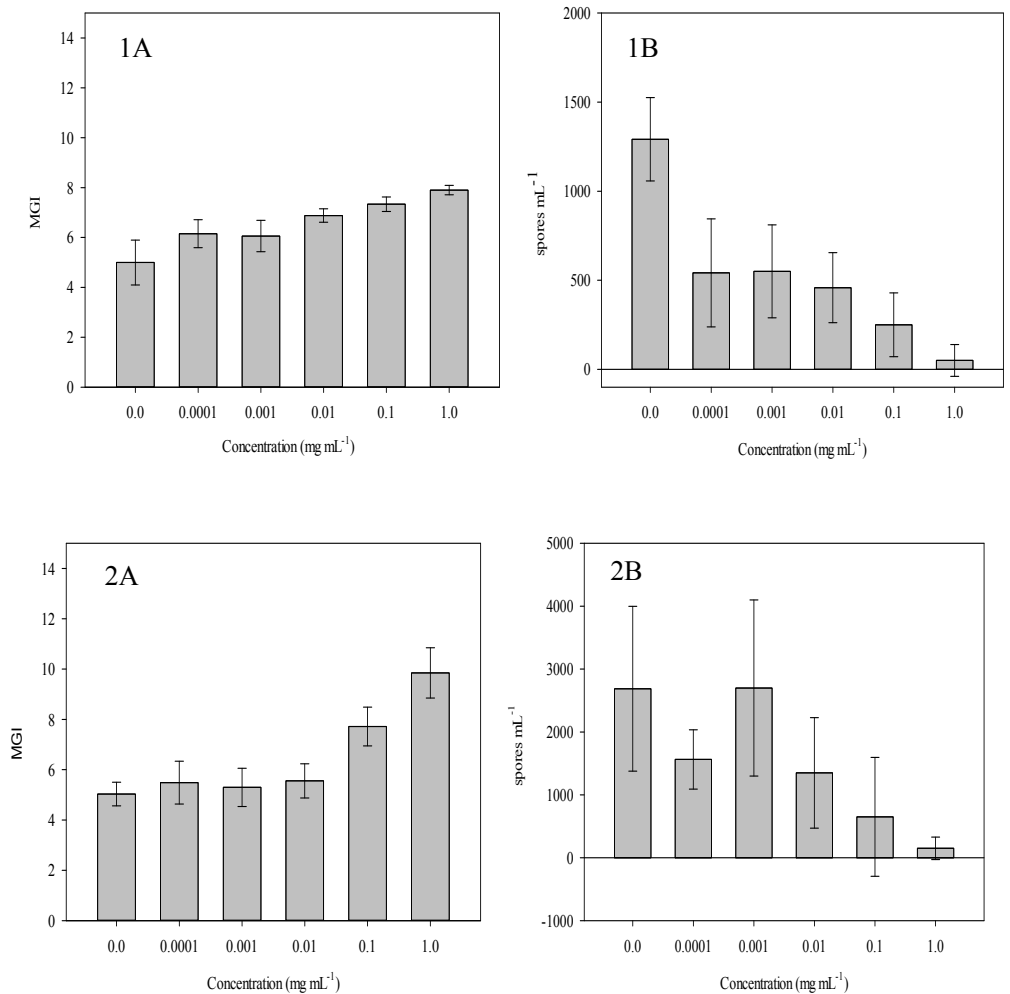

Figure 1. Mycelial growth index (MGI) (A) and sporulation (B) of Bipolaris oryzae isolate of intermediate aggressiveness (1) and high aggressiveness (2) at different concentrations of methanol extract of Heteranthera reniformis leaves. *Error bars represent confidence intervals $(\mathrm{p} \leq 0.05)$. 
For spore production to occur it is necessary that the hyphae get enough nourishment to develop adequately so that they can differentiate and form the reproductive structures (BEDENDO; PRABHU, 2016). When hyphae grow in media containing stressors or inhibitors, morphological changes can occur, such as membrane and cell wall damage that alters the cells' functionality and compromise fungal growth and sporulation (PONTIN et al., 2015).

When comparing the concentrations of $H$. reniformis methanol extract on the high aggressiveness isolate of $B$. oryzae, it was verified that the control MGI did not differ from the concentrations of $0.0001,0.001$ and $0.01 \mathrm{mg} \mathrm{mL}^{-1}$, and these had lower values compared to the other concentrations (Figure 1.2A). At extract concentration of $0.1 \mathrm{mg} \mathrm{mL}^{-1}$, there was an increase in MGI compared to the control treatment, but at this concentration the MGI was lower than that verified in the treatment with the extract at $1 \mathrm{mg} \mathrm{mL}^{-1}$.

For the high aggressiveness isolate, control treatment had the highest spore count and did not differ from most concentrations except for $1 \mathrm{mg} \mathrm{mL}-1$ (Figure 1. 2B). The concentration of $1 \mathrm{mg} \mathrm{mL} L^{-1}$ led to the lowest number of spores $\mathrm{mL}^{-1}$ and differed from all concentrations except for the treatment $0.1 \mathrm{mg} \mathrm{mL}^{-1}$, and the result was also verified for the isolate with intermediate aggressiveness.

In a study conducted by Dorneles et al. (2018), Curcuma longa extracts inhibited mycelial growth and $B$. oryzae sporulation; however, the extract concentrations that caused inhibitions were 40 and $80 \mathrm{mg} \mathrm{mL}^{-1}$, that is, 40 and 80 times higher than the concentration of $1 \mathrm{mg} \mathrm{mL} \mathrm{m}^{-1}$ used in the present study.

In contact with the plant material, the solvents diffuse and solubilize compounds with similar polarities (GURJAR et al., 2012). As the extract concentration increases, antifungal compound concentration increases, but there is also the possibility of inhibition caused by other factors, such as $\mathrm{pH}$ changes, which may also contribute to affecting fungal development. Media $\mathrm{pH}$ was measured after the addition of the extracts and no changes in $\mathrm{pH}$ were observed.

Colony characteristics of $B$. oryzae intermediate isolate were also modified by the concentrations of 1 and $2 \mathrm{mg} \mathrm{mL}^{-1}$ of the methanol extract of $H$. reniformis leaves compared to the controls (Table 6). For both concentrations, circular colony form, flat elevation, filamentous margin and lighter colony color, with filamentous mycelia, were observed. The controls showed similar morphological and color characteristics except for PDA, which had flat elevation and bluish gray color.

Table 6. Form, elevation, margin and color of Bipolaris oryzae colony for the isolate of intermediate agressiveness at different concentrations of methanol extract of Heteranthera reniformis leaves.

\begin{tabular}{lcccc}
\hline \multicolumn{1}{c}{ Treatment } & Form & Elevation & Margin & Color $^{1}$ \\
\hline $\mathrm{PDA}^{2}$ & irregular & flat & filamentous & very dark bluish gray (gley 2 3.10BG) \\
$\mathrm{DMSO}^{3}$ & irregular & papillate & filamentous & dark greenish gray (gley 1 4.5GY) \\
$0 \mathrm{mg} \mathrm{mL}$ & irregular & papillate & filamentous & dark greenish gray (gley 1 4.5GY) \\
$1 \mathrm{mg} \mathrm{mL}$ & circular & flat & entire & light blue gray (gley 2 7.5PB) \\
$2 \mathrm{mg} \mathrm{mL}^{-1}$ & circular & flat & entire & light gray (gley 1.7N) \\
\hline
\end{tabular}

${ }^{1}$ Color based on Munsell soil color charts (1975); ${ }^{2}$ PDA: Potato dextrose agar culture medium; ${ }^{3}$ DMSO: Dimethyl sulfoxide.

\section{Experiment 3}

Spore length of $B$. oryzae isolate of intermediate aggressiveness was significantly affected by the treatments (Table 7). Although the DMSO adjuvant reduced spore length in comparison to PDA control, $H$. reniformis methanol extract reduced spore length significantly more than DMSO.

Table 7. Bipolaris oryzae spore length in medium containing methanol extract of $H$. reniformis leaves.

\begin{tabular}{rccc}
\hline Treatment & \multicolumn{2}{c}{ Length $(\mu \mathrm{m})$} & \\
\hline PDA $^{1}$ & 73.78 & & $\mathrm{a}^{3}$ \\
PDA+DMSO $^{2}$ & 65.15 & & $\mathrm{~b}$ \\
Methanol extract & 59.66 & & $\mathrm{c}$ \\
\hline $\mathrm{CV}(\%)$ & & 8.1 & \\
\hline
\end{tabular}

${ }^{1}$ PDA: Potato dextrose agar; ${ }^{2}$ DMSO: Dimethyl sulfoxide; ${ }^{3}$ Means followed by the same letter within a column do not differ by Duncan's test $(\mathrm{p} \leq 0.05)$. 
B. oryzae spore dimensions vary according to the isolate from approximately 57 to $137 \mu \mathrm{m}$ (KUMAR et al. 2016; VALARMATHI; LADHALAKSHMI, 2018). An increase in spore volume may indicate that the spore contains more endogenously available nutrients, in addition to a higher number of nuclei, which can promote changes in pathogen aggressiveness (PHILLIPS; MARGOSAN; MACKEY, 1987).

\section{Experiment 4}

Contrast analysis revealed that the control treatments with DMSO, or solvent residue, did not interfere in the germination of B. oryzae spores (isolate of intermediate aggressiveness) (Table 8).
On the other hand, the addition of $H$. reniformis methanol extract at concentrations of 0.4 and $0.8 \mathrm{mg} \mathrm{mL} \mathrm{m}^{-1}$ (contrast 3) resulted in significant sporulation inhibition compared to the controls.

The inhibition of $B$. oryzae spore germination by compounds from plants has also been found in other studies. Significant inhibitions of spore germination of three isolates of Bipolaris sp. occurred after 24 hours of incubation in solution containing Ocimum basilicus essential oils at the concentrations of 40 and $80 \mathrm{mg} \mathrm{mL} \mathrm{mL}^{-1}$ (ELSHERBINY; EL-KHATEEB; AZZAZ, 2016). The essential oil of Acacia farnesiana at the concentration of $2 \%(v / v)$ totally inhibited mycelial growth and the germination of $B$. oryzae spores, and of other fungi (UDOMSILP et al., 2009).

Table 8. Percentage of non-germinated B. oryzae spores in solution containing methanol extract of $H$. reniformis leaves at concentrations of 0.4 and $0.8 \mathrm{mg} \mathrm{mL}^{-1}$

\begin{tabular}{lcc}
\hline \multicolumn{1}{c}{ Contrasts } & \multicolumn{2}{c}{ \% non-germinated B. oryzae spores } \\
\cline { 2 - 3 } & $0.4 \mathrm{mg} \mathrm{mL}^{-1}$ & $0.8 \mathrm{mg} \mathrm{mL}^{-1}$ \\
\hline $\mathrm{C}^{2}{ }^{2}-(\mathrm{T} 1) \mathrm{x}(\mathrm{T} 2)$ & $(17.50)^{\mathrm{ns}} \times(19.16)$ & $(33.33)^{\mathrm{ns}} \times(42.91)$ \\
$\mathrm{C} 2-(\mathrm{T} 2) \mathrm{x}(\mathrm{T} 3)$ & $(19.16)^{\mathrm{ns}} \times(20.00)$ & $(42.91)^{\mathrm{ns}} \times(43.40)$ \\
$\mathrm{C} 3-(\mathrm{T} 1+\mathrm{T} 2+\mathrm{T} 3) \times(\mathrm{T} 4)$ & $(18.88)^{*} \times(61.81)$ & $(39.88)^{*} \times(68.44)$ \\
\hline $\mathrm{CV}(\%)$ & 45.2 & 32.9 \\
\hline
\end{tabular}

${ }^{*}$ or ${ }^{\text {ns }}$ significant and non-significant contrasts $(\mathrm{p} \leq 0.05) ; \mathrm{C} 1, \mathrm{C} 2$ and $\mathrm{C} 3$ : Contrasts 1 to 3 .

H. reniformis methanol extract potentially has several metabolites in its composition, and it is necessary to use isolation techniques based on activity bioassays to identify the compound or compounds responsible for the fungicide activity observed in this study.

\section{CONCLUSIONS}

The mycelial growth of $B$. oryzae is stimulated and its sporulation is suppressed by hexane, ethyl acetate, and methanol extracts of $H$. reniformis leaves. The methanol extract is the most active. Colony morphology is changed when the fungus grows in media containing either hexane, ethyl acetate or methanol $H$. reniformis leaf extracts. The concentration of $1 \mathrm{mg} \mathrm{mL}^{-1}$ of the methanol extract stimulates mycelial growth and suppresses $B$. oryzae sporulation. Isolates with different degrees of aggressiveness have stimulated mycelial growth and reduced sporulation when cultivated in media containing methanol extract of $H$. reniformis. The high aggressiveness isolate has the lowest sensitivity to the compounds present in the methanol extract of $H$. reniformis leaves. The length and germination of $B$. oryzae spores of intermediate aggressiveness are reduced by the methanol extract of $H$. reniformis.

\section{ACKNOWLEDGMENTS}

This study was supported by Rio Grande do Sul State Research Support Foundation (FAPERGS), Call 02/2017 - PqG/N.Proc. 17/2551-0000919-3; The authors would like to thank the Coordination for the Improvement of Higher Education Personnel (CAPES) - Financing Code 001, for granting a scholarship to the first author; To CNPq for the Research Fellowship of several authors: Dr. Dirceu Agostinetto /N.Proc. 308363/2018-3 CNPq.

\section{REFERENCES}

BEDENDO, I. P.; PRABHU, A. S. Doenças do Arroz. In: AMORIN, L. et al. (Eds.) Manual de Fitopatologia: Doenças das plantas cultivadas. 5 ed. São Paulo, SP: Agronômica Ceres. 2016. v. 2, cap. 10, p. 87-99.

BHUTIA, D. D.; RAMEN, Y. Z.; SAHA, K. J. Antifungal activity of plant extracts against Colletotrichum musae, the post-harvest anthracnose pathogen of banana cv. Martaman. Nutrition \& Food Science, 46: 2-15, 2016.

CAMARGO, L. E. A. Mecanismos de variabilidade 
genética de agentes fitopatogênicos. In: FILHO, A. B.; KIMATI, H.; AMORIN, L. (Eds.) Manual de Fitopatologia: doenças das plantas cultivadas. 3 ed. São Paulo, SP: Agronômica Ceres, 1995. v. 2. p. 455-469.

CANTRELl, C. L.; DAYAN, F. E.; DUKE, S. O. Natural products as sources for new pesticides. Journal of Natural Product, 75: 1231-1242, 2012.

CONAB - Companhia Nacional de Abastecimento. Acompanhamento da safra brasileira de grãos 2019/2020 - Sétimo levantamento. Disponível em: https://www.conab.gov.br/info-agro/safras/graos/ boletim-da-safra-de-graos/. Acesso em: 11 mai. 2020.

DAS, S. K. Screening of bioactive compounds for development of new pesticides: A mini review. Universal Journal of Agricultural Research, 4:1520,2016

DORNELES, K. R. et al. Control of Bipolaris oryzae (Breda de Haan) using Curcuma longa (Linnaeus) extract and effect of this extract on rice seed physiology, Revista Caatinga, 31: 1-7, 2018

ELSHERBINY, E. A.; EL-KHATEEB, A. Y.; AZZAZ, N. A. Chemical composition and fungicidal effects of Ocimum basilicum essential oil on Bipolaris and Cochliobolus species. Journal of Agricultural Science and Technology, 18: 11431152, 2016.

FARIA, A. D.; AMARAL, M. C. Pontederiaceae. In: WANDERLEY, M.G.L. et al. (Eds.) Flora fanerogâmica do Estado de São Paulo. São Paulo, SP: Instituto de Botânica, 2005. v. 4, p. 325-330.

GURJAR, M. S. et al. Efficacy of plant extracts in plant disease management. Agricultural Science, 3: 425-433, 2012.

IMATOMI, M. et al. Phytotoxic effect of bioactive compounds isolated from Myrcia tomentosa (Myrtaceae) leaves. Biochemical Systematics and Ecology, 46: 29-35, 2013.

KHAN, Z. S.; NASREEN, S. Phytochemical analysis, antifungal activity and mode of action of methanol extracts from plants against pathogens. Journal of Agricultural Technology, 6: 793-805, 2010 .

KUCK, K. H.; LEADBEATER, A.; GISI, U. FRAC mode of action classification and resistance risk of fungicides. In: KRAMER, W.; SCHRIMER, U.; JESCHKE, P.; WITSCHEL, M. (Eds.) Modern crop protection compounds, 2 . ed. Germany: Wiley-Vch Weinheim, 2012. v. 2, cap. 14, p.539-557.
KUMAR, A. et al. Morpho-molecular diversity of Bipolaris oryzae causing brown spot of paddy. Indian Journal of Agricultural Sciences, 86: 615 $620,2016$.

MAYER, A. M.; STAPLES, R. C.; GIL-AD, N. L. Mechanisms of survival of necrotrophic fungal plant pathogens in hosts expressing the hypersensitive response. Phytochemistry, 58: 33-41, 2001.

MINZ, S.; SAMUEL, C. O.; TRIPATHI, S .C. The effect of plant extracts on the growth of wilt causing fungi Fusarium oxysporum. Journal of Pharmacy and Biological Sciences, 4: 13-16, 2012.

MUNSELL SOIL COLOR COMPANY. Munsell soil color charts. Munsell color, Macbeth Division of Kollmorgen Corporation, Baltimore, Maryland, USA. 1975.

NCUBE, N.; AFOLAYAN, S. A. J.; OKOH, A. I. Assessment techniques of antimicrobial properties of natural compounds of plant origin: Current methods and future trends. African Journal of Biotechnology, 7: 1797-1806, 2008.

MARTÍNEZ-ROMERO, D. et al. The use of a natural fungicide as an alternative to preharvest synthetic fungicide treatments to control lettuce deterioration during postharvest storage. Postharvest Biology and Technology, 47: 54-60, 2008.

MOREIRA-NUNEZ, V. Influência da compatibilidade sexual e vegetativa na variabilidade morfofisiológica e agressividade de populações de Bipolaris oryzae. 2017. 106 f. Dissertação (Mestrado em Fitossanidade: Área de Concentração em Fitopatologia) - Universidade Federal de Pelotas, Pelotas, 2017.

PELCZAR JR, M. J. Manual of microbiological methods. New York, NY: McGraw-Hill Book Co., $1957.315 \mathrm{p}$

PHILLIPS, D. J.; MARGOSAN, D. A.; MACKEY, B. E. Size, nuclear number, and aggressiveness of Botrytis cinerea spores produced on media of varied glucose concentrations. Phytopathology, 77: 1606$1608,1987$.

PONTIN, M. et al. Allium sativum produces terpenes with fungistatic properties in response to infection with Sclerotium cepivorum. Phytochemistry, 115: 152-160, 2015

ROSSMAN, A. Y.; MANAMGODA, D. S.; HYDE, K. D. Proposal to conserve the name Bipolaris against Cochliobolus (Ascomycota: Pleosporales: Pleosporaceae). Taxon, 62: 1331-1332, 2013. 
SILVA, W. R. et al. Fungitoxicidade de extratos vegetais e óleo essencial de alecrim no crescimento micelial e esporulação de Bipolaris oryzae. Magistra cruz das Almas-Ba, 29: 257-265, 2018

SPARKS, T. C.; HAHN, D. R.; GARIZI, N. V. Natural products, their derivatives, mimics and synthetic equivalents: role in agrochemical discovery. Pest Management Science, 73: 700-715, 2017.

TATA, S. et al. Comparative studies on the effect of aqueous and methanolic extracts of some botanicals on growth and sporulation of Colletotrichum graminicola. International Journal of Innovative Research and Advanced Studies, 5: 1-7, 2018.

UDOMSILP, J. et al. Antifungal properties of essential oils from thai medical plants against rice pathogenic fungi. Asian Journal of Food and Agroindustry, s/v, 24-30, 2009.

VALARMATHI, P.; LADHALAKSHMI, D. Morphological characterization of Bipolaris oryzae causing brown spot disease of rice. International Journal of Current Microbiology Applied Science, 7: 161-170, 2018. 